\title{
Study of TH 1 and TH 2 activity in women with threatened miscarriages
}

\author{
Madhu Jain, Zahida Hassan, Shuchi Jain*
}

Department of Obstetrics and Gynecology, Institute of medical Sciences, BHU, Varanasi, India

Received: 21 September 2015

Revised: 22 September 2015

Accepted: 23 October 2015

\section{*Correspondence:}

Dr. Shuchi Jain,

E-mail: shuchi.gyno81@gmail.com

Copyright: $\odot$ the author(s), publisher and licensee Medip Academy. This is an open-access article distributed under the terms of the Creative Commons Attribution Non-Commercial License, which permits unrestricted non-commercial use, distribution, and reproduction in any medium, provided the original work is properly cited.

\begin{abstract}
Background: Successful pregnancy is associated with T helper-type 2 (Th2) immunity and is helpful in maintaining pregnancy, while T helper type-1 (Th1) activity is responsible for deleterious effects.

Methods: The study comprised of two groups: Group I- Threatened abortions in first trimester $(n=60)$ subdivided in two groups: $1 \mathrm{~N}$ - one who continued pregnancy $(n=38)$, and another, 1A- who aborted $(n=22)$, and Group II- 40 pregnant women in first trimester who later delivered at term without any history of abortion in the past. Blood was collected and analyzed for IL-2 and IL- 6 by ELISA kit.

Results: Th1 activity (IL-2) was higher in threatened abortion group irrespective of whether continuing their pregnancy or aborting in comparison to control $(\mathrm{p}<0.001)$. On the other hand, Th2 activity (IL6) was decreased (p $<0.001)$ in both the groups of threatened abortions.

Conclusions: The patients with threatened abortion have a definite increase in Th1 activity and decrease in Th2 activity whether aborting or continuing their pregnancy in comparison to normal pregnant women without any history of spontaneous abortion in the past.
\end{abstract}

Keywords: Recurrent miscarriages, TH 1 activity in pregnancy, TH 2 activity in pregnancy

\section{INTRODUCTION}

Threatened miscarriage refers to an intrauterine viable clinical pregnancy accompanied by an intrauterine source of painless vaginal bleeding and successful or adverse pregnancy outcome. The prevalence of miscarriages among pregnant women varies between 0.5 to $1.0 \%$. The incidence is greater than expected by chance alone, since $10-15 \%$ of all clinical recognized pregnancies end in miscarriages.

The cause of miscarriage is multifactorial. The aetiology of recurrent miscarriages can be divided into six major groups, such as genetic, anatomical, metabolic, infectious, hormonal or immunological. The aetiology in $30 \%$ of miscarriages is unknown and $80 \%$ of this unexplained pregnancy failures are proposed to have an immunological background. The cytokine network has been suggested to be involved in positive or negative evolution of ongoing pregnancies. Interleukin 2 has deleterious effect on the conceptions and has the characteristic of $\mathrm{T}$ helper type - 1 cells activity (Th-1 response) which induces several cytotoxic and inflammatory reactions via cell mediated immunity against the conceptus. On the other hand, $\mathrm{T}$ - helper type - 2 cells secrete interleukin 6 and are associated with humoral immunity (Th-2 response). The successful outcome is associated with down regulation of Th1 activity and enhancement of Th2 activity. ${ }^{5-7}$

As we know, many women with threatened miscarriage go on to have a successful pregnancy. So, we designed a study with the objectives (1) to assess the interleukin 2 and interleukin 6 levels in pregnant women with 
threatened miscarriages; (2) to compare these cytokine profiles in threatened miscarriage women who had a successful pregnancy with those who underwent miscarriage; (3) to establish the cut off levels of these cytokines in pregnancy to predict the pregnancy outcomes.

\section{METHODS}

The study group comprised of 60 pregnant women of less than 20 weeks of gestation with threatened miscarriage (Group I). These patients underwent the clinical and investigative protocol including ultrasonography, and blood tests to find our any possible anatomical, endocrinological, infectious, genetic, and immunological cause of miscarriage. Of these women, one subgroup of threatened miscarriage consisting of 38 women had continued their pregnancy (Group I N) and the rest 22 patients underwent miscarriage (Group I A). All patients were seen fortnightly and a proper antenatal follow-up was done and outcome of pregnancy was noted. A group of 40 pregnant healthy women of less than 20 weeks of gestation with no history of bleeding $\mathrm{P} / \mathrm{V}$ and having normal ultrasonographic evidence were selected as controls (Group II). An approval from Institute Ethical Committee was obtained.

\section{Measurement of Cytokines}

Serum concentration of interleukin 2 (IL2) and interleukin 6 (IL6) was assessed by a high sensitivity ELISA kit, provided by OSB agencies, New Delhi, obtained from Coulte / Immunotech (France) which consisted of sandwitch ELISA for which manufacturer's protocol was followed. Each sample was tested in a blinded fashion. The recombinant reference cytokine samples served as positive controls for calibration. The sensitivity of the test for IL2 was 5 and for IL6, $3 \mathrm{pg} / \mathrm{ml}$.

The statistical analysis was done using SPSS-16 version for windows. $\mathrm{Z}$ test was used to test the significant difference in mean values of study and control group. The one way analysis of variance parametric test was applied to find out the significant difference among the mean levels of IL2 \& IL6 after log transformation. If this test revealed significant difference then Multiple Range test (SNK) was used to find pair wise significance difference. ROC curve technique was used to find out the cut off level of IL-2 and 6 and to predict the pregnancy outcome.

\section{RESULTS}

Table 1: Comparative characteristics of the study groups.

\begin{tabular}{|c|c|c|c|c|}
\hline \multirow[b]{2}{*}{ Characteristics } & \multicolumn{2}{|c|}{ Study groups } & \multirow[b]{2}{*}{$\begin{array}{c}\mathrm{z} \\
\text { value }\end{array}$} & \multirow[b]{2}{*}{$\begin{array}{c}\mathbf{p} \\
\text { value }\end{array}$} \\
\hline & $\begin{array}{c}\text { Cases } \\
\text { (Group } \\
\text { I, } \\
\mathrm{n}=60 \text { ) }\end{array}$ & $\begin{array}{c}\text { Control } \\
\text { (Group } \\
\text { II, } \\
\mathrm{n}=60 \text { ) }\end{array}$ & & \\
\hline Age (years) & $\begin{array}{l}27.76 \pm \\
3.97\end{array}$ & $\begin{array}{l}29.00 \pm \\
4.54\end{array}$ & 1.59 & 0.114 \\
\hline Gravida & $\begin{array}{l}2.33 \pm \\
0.92\end{array}$ & $\begin{array}{l}1.76 \pm \\
0.62\end{array}$ & 3.98 & $\begin{array}{l}< \\
0.001\end{array}$ \\
\hline Parity ${ }^{*}$ & $\begin{array}{l}0.46 \pm \\
0.57\end{array}$ & $\begin{array}{l}0.70 \pm \\
0.65\end{array}$ & -- & $\begin{array}{l}< \\
0.03\end{array}$ \\
\hline $\begin{array}{l}\text { Gestational age } \\
\text { (weeks) }\end{array}$ & $\begin{array}{l}9.30 \pm \\
2.76 \\
\end{array}$ & $\begin{array}{l}10.20 \pm \\
3.20\end{array}$ & 1.65 & 0.10 \\
\hline $\begin{array}{l}\text { Number of } \\
\text { abortions }\end{array}$ & $\begin{array}{l}0.86 \pm \\
0.68\end{array}$ & --- & -- & --- \\
\hline
\end{tabular}

*Mann whitney U test has been applied.

The mean \pm SD age of pregnant women was $27.76 \pm 3.97$ and $29.00 \pm 4.54$ years in the threatened miscarriage and control groups and both the groups were comparable $(\rho=0.114)$. The mean gravida was 2.33 in threatened miscarriage group in comparison to 1.76 in control group. Both the groups were also comparable in respect of parity and gestational age (Table 1).

The measurement of IL2 in group I A (group of patients with threatened miscarriage who went into miscarriage) showed a significantly higher value $(\rho<0.001)$ than that of those who continued their pregnancy (Group I N; $342.27 \pm 417.91$ Vs 56.05 \pm 55.95 ; Table 2 and 3 ).

Table 2: Interleukin-2 and Interleukin-6 cytokines among the study groups.

\begin{tabular}{|c|c|c|c|c|c|}
\hline \multirow[b]{2}{*}{ Variables } & \multirow{2}{*}{$\begin{array}{l}\text { Study Group } \\
\text { Group I A } \\
n=22\end{array}$} & \multicolumn{2}{|c|}{ Controls } & \multirow{2}{*}{$\begin{array}{l}\text { F value } \\
\text { K.W } \\
\text { test }\end{array}$} & \multirow[b]{2}{*}{ p value } \\
\hline & & $\begin{array}{l}\text { Group I N } \\
\mathrm{n}=38\end{array}$ & $\begin{array}{l}\text { Group II } \\
n=60\end{array}$ & & \\
\hline IL2 & $\begin{array}{l}342.27 \pm 417.91 \\
(5-1550)\end{array}$ & $\begin{array}{l}56.05 \pm 55.95 \\
(0-170)\end{array}$ & $\begin{array}{l}7.36 \pm 10.34 \\
(0-40)\end{array}$ & \multirow[t]{2}{*}{97.95} & \multirow[t]{2}{*}{$<0.001$} \\
\hline $\log$ IL2 & $2.28 \pm 0.59$ & $1.50 \pm 0.56$ & $0.67 \pm 0.36$ & & \\
\hline IL6 & $\begin{array}{l}42.45 \pm 59.68 \\
(0-148)\end{array}$ & $\begin{array}{l}159.0 \pm 133.80 \\
(35-615)\end{array}$ & $\begin{array}{l}352.96 \pm 407.42 \\
(20-1350)\end{array}$ & \multirow[t]{2}{*}{23.82} & \multirow[t]{2}{*}{$<0.001$} \\
\hline $\log$ IL6 & $1.41 \pm 0.65$ & $2.09 \pm 0.30$ & $2.26 \pm 0.53$ & & \\
\hline
\end{tabular}

Figures in parenthesis show the range. 
Besides IL2 level in threatened miscarriage group (IA + IN) was significantly higher as compared with control as a whole. On the contrary, the IL6 levels in Group I A showed significantly lower values $(42.45 \pm 59.68)$ in comparison to group IN $(159.0 \pm 133.80)$ as well as control (Group II, 352.96 \pm 407.42 ).

The cut off value of IL2 and IL6 was calculated through ROC curve to diagnose the patients having the risk of miscarriage. The cut off value for IL2 and IL6 were taken as $\geq 5.5 \mathrm{pg} / \mathrm{ml}$ and $\leq 150 \mathrm{pg} / \mathrm{ml}$ respectively (covering $96.3 \%$ and $96.4 \%$ area each). The sensivity, specificity, positive predictive value, negative predictive value, and accuracy were $95.2 \%, 44.9 \%, 34.5 \%, 96.9 \%$, and $86.6 \%$ for IL2, and $76.2 \%, 49.3 \%, 31.4 \%, 87.2 \%$, and $55.6 \%$ for IL-6 respectively (Table 4).

Table 3: Multiple range (SNK test values) nonparametric test.

\begin{tabular}{|l|l|ll|}
\hline Cytokines & I A Vs I N & I A Vs II & I N Vs II \\
\hline $\log$ IL2 & $8.31^{* * * *}$ & $18.81^{* * * *}$ & $11.88^{* * * *}$ \\
\hline \hline $\log$ IL 6 & $7.23^{* * *}$ & $9.73^{* * *}$ & $2.34^{* * *}$ \\
\hline
\end{tabular}

\section{DISCUSSION}

The cytokine network has been suggested to be involved in positive or negative evolution of ongoing pregnancies. ${ }^{6-9}$ IL-2, IFN $\gamma$ and TNF $\alpha$ cytokines have been found to have a deleterious effect on conceptus. These cytokines are characteristic of T helper type-1 cells which induce several cytotoxic and inflammatory reactions. $\mathrm{T}$ helper type-2 (Th2) cells, on the other hand, secrete IL 46, 10 and 13 and are associated with humoral immunity and helpful in maintaining a normal pregnancy.

Our results too support this as we have also found that all patients of threatened miscarriage who went into miscarriage (IA) had higher values of IL2 $(\mathrm{p}<0.001)$ and lower values of IL6 $(\mathrm{p}<0.001)$ when compared to group IN and control.

Several studies conducted on human pregnancy showed that successful pregnancy occurred in a T helper 2 biased situation while $\mathrm{T}$ helper $\mathrm{I}$ type immunity lead to pregnancy failure. ${ }^{6,7,10}$ These studies mainly focused on unexplained recurrent aborters and compared them with control (Normal pregnancy). Recurrent spontaneous aborters produced higher concentration of Th1 cytokines in first trimester, ${ }^{7}$ and at delivery 6 than the women with a history of normal pregnancy, Wilson et al reported abnormally high IL-2 receptor levels in non pregnant women with a history of recurrent miscarriages than in women with no miscarriage $(\mathrm{p}<0.05) .{ }^{11}$ It has been demonstrated that increased $\mathrm{Th} 2$ response and $\mathrm{T}$ helper type- 2 cells at the implantation site may contribute to a successful pregnancy in recurrent spontaneous aborters. ${ }^{10}$ Low IL6 values have been also encountered by others in women with threatened miscarriage as in our study. ${ }^{12}$

However, few have come across elevated circulating IL$1 \mathrm{~B}$ and TNF- $\alpha$ and unaltered IL- 6 in first trimester pregnancies complicated by threatened miscarriage with an adverse pregnancy outcome. ${ }^{13}$ They concluded that this distinct immune response was relevant to predict negative outcome of pregnancy. In our study, we found significantly higher levels of IL-2 and lower values of IL6 in threatened aborters who aborted in comparison to control. The reason for this negative outcome is due to lack of balance of various cytokines that stimulate placental growth and rapid invasion of trophoblastic cells within the maternal endometrium. Communication between trophoblastic and decidual cells is mediated by cytokines and cell surface receptors. Cytokines are produced by trophoblastic and lymphomyeloid cells. Lymphomyeloid cells present within the deciduas include $\mathrm{T}$ lumphocytes (CD8+), macrophages, and natural killer cells (NK, CD56+). Contrary to our result, some have found a greater Th1 to Th2 shift in pregnant women with recurrent spontaneous aborters compared to control of similar age. ${ }^{14}$ It could have been due to varied production of cytokines throughout the pregnancy. ${ }^{9,15}$ It could also depend whether control sample was taken from pregnant women at term, during labour5 or in a non pregnant women or in first trimester of pregnancy. ${ }^{7}$

As a result of intercellular communication, changes of expression of types and qualities of cytokines occur. These changes in expression include colony stimulating factors (CSF), tumor necrosis factor (TNF), alfa interferons (INF), transforming growth factor $\beta$, and several interleukins $(6 \& 8)$. It is the balance of various cytokines that dictates success or failure of a pregnancy.

This study may be reviewed with 2 caveats,

(1) Firstly, the data reflected here are related to the events in the maternal blood cells in the periphery and not to the placenta itself as events related to the maternal- foetal interface were not investigated.

Table 4: Showing the various screening indices for IL2 and IL6 at a selected cut off point obtained by ROC curve.

\begin{tabular}{|l|l|l|l|l|l|l|l|}
\multicolumn{2}{|c|}{$\begin{array}{l}\text { Cut } \\
\text { Variables } \\
\text { off } \\
\text { point }\end{array}$} & Area & Sensitivity & Specificity & $\begin{array}{l}\text { Positive } \\
\text { Predictive } \\
\text { value (\%) }\end{array}$ & $\begin{array}{l}\text { Negative } \\
\text { predictive } \\
\text { value (\%) }\end{array}$ & $\begin{array}{l}\text { Accuracy } \\
(\%)\end{array}$ \\
\hline IL2 & $\geq 5.5$ & 0.963 & 95.2 & 44.9 & 34.5 & 96.9 & 86.6 \\
\hline \hline IL6 & $\leq 150$ & 0.642 & 76.2 & 49.3 & 31.4 & 87.2 & 55.6 \\
\hline
\end{tabular}


(2) Secondly, this study does not show a cause and effect relationship between Th1 type reactivity and pregnancy loss for e.g. an inflammatory maternal response to a dead foetus, could well manifest Th1 profile also.

\section{CONCLUSIONS}

The IL-2 levels were found to be significantly higher for pregnant women having threatened miscarriage with subsequent miscarriage as compared to those who had no miscarriage. The IL-6 level was also found to be lower in threatened aborters who subsequently had miscarriage in comparison to those pregnant women without any miscarriage or with threatened miscarriage but continuing their pregnancy. These levels demonstrate a relationship between $\mathrm{T}$ helper cells and pregnancy loss and might help to adopt the preventive and therapeutic methods for solving the problem. This observation would also throw a light for development of methods to manipulate the maternal immune system towards a Th-2 type situation that would favour the continuation of pregnancy to term.

\section{Funding: No funding sources}

Conflict of interest: None declared

Ethical approval: The study was approved by the Institutional Ethics Committee

\section{REFERENCES}

1. Adashi EY. The potential relevance of cytokines to ovarian physiology: the emerging role of resident ovarian cells of the white blood cells series. Endocr Rev. 1990;11: 454-64.

2. Adashi EY, Resnick CE. Antagonistic interactions of transforming growth factors in the regulation of granulose cells differentiation. Endocrinol. 1986;119:1879-81.

3. Mosmann T R, Coffman RL. Th1 and Th2 cells: different patterns of lymphokine secretion lead to different functional properties. Annu Rev Immunol. 1989;7:145-73.

4. Romagnani S. Lymphokine production by human T cells in disease sates. Annu Rev Immunol. 1994;12:227-57.

5. Monsmann TR, Sad S. The expanding universe of Tcell subsets. Immunol Today. 1996;17:138-46.

6. Makhseed M, Raghupathy R, Azizieh F, Omu A, AlShamali E, Ashkanani L. Th1 and Th 2 cytokine profiles in recurrent miscarriages with successful pregnancy and subsequent miscarriages. Hum Reprod. 2001;16:2219-26.

7. Raghupathy R, Makhseed M, Azizieh F, Omu A, Gupta M, Farhat R. Cytokine production by maternal lymphocytes during normal pregnancy and in unexplained recurrent spontaneous miscarriage. Hum Reprod. 2000;15:713-8.

8. Hill JA. Immunologic factors in recurrent spontaneous miscarriages. In: Kurpisz M, Fernandez $\mathrm{N}$, eds. Immunology of Human Reproduction. Oxford: Bios Scientific. 1995:401-24.

9. Marzi M, Vigano A, Trabattoni D, Villa ML, Salvaggio A, Clerici E. Characterization of type 1 and type 2 cytokine production profile in physiologic and pathologic human pregnancy. Clin Exp Immunol. 1996;106:127-33.

10. Michimata T, Tsuda H, Sakai M, Fujimura M, Nagata K, Nakamura M. Accumulation of CRTH2positive T-helper @ and T cytotoxic cells at implantation site of human deciduas in a prostaglandin D2 mediated manner. Mol Hum Reprod. 2002;8:181-7.

11. Wilson R, Moore J, Jenkin C. Abnormal IL-2 receptir levels in non-pregnant women with a history of recurrent miscarriage. Hum Reprod. 2003;18(7):1529-30.

12. Paradisi R, Maldini-Casadei M, Boni P, Busacchi P, Porcu E. T-helper 2-cytokine levels in women with threatened miscarriage.Eur J Obstet Gynecol Reprod Biol. 2003;111(1):43-9.

13. Vitoratos N, Papadias C, Economou E, Makrakis E, Panoulis C, Creatsas G. Elevated circulating IL-1 $\beta$ and TNF-alpha, and unaltered IL-6 in first-trimester pregnancies complicated by threatened abortion with an adverse outcome. Mediators Inflamm. 2006;30485:1-6.

14. Bates MD, Quenby S, Takuwa K, Johnson PM, Vince GS. Aberrant cytokine production by peripheral blood mononuclear cells in recurrent pregnancy loss? Hum Reprod. 2002;17:2439-44.

15. Trachot-Diallot J, Gras G, Parnet-Mathieu F, Benveniste O, Marcé D, Roques P. Modulations of cytokine expression in pregnant women. Am J Reprod Immunol. 1997;37:215-26.

Cite this article as: Jain M, Hassan Z, Jain S. Study of TH 1 and TH 2 activity in women with threatened miscarriages. Int J Reprod Contracept Obstet Gynecol 2015;4:1918-21. 